\title{
Response to letter to the editor regarding "Use of intra-operative stimulation of brainstem lesion target sites for frameless stereotactic biopsies."
}

\author{
Jason Labuschagne ${ }^{1,2}$ (D) \\ Received: 5 May 2021 / Accepted: 9 May 2021 / Published online: 24 May 2021 \\ (C) The Author(s), under exclusive licence to Springer-Verlag GmbH Germany, part of Springer Nature 2021
}

\section{Dear Editor:}

We really appreciate the comments and questions brought by Dr Cabrera regarding our manuscript [1].

We feel that in all likelihood both stimulation techniques, either the monopolar or the bipolar technique, would be adequate in assessing the corticospinal tract and indeed our device design would be able to accommodate both stimulation techniques for the detection of the descending pathways. We opted however to use bipolar stimulation as we were concerned, given the very compact configuration of the long tracts within the brainstem, that the current spread of the monopolar stimulation $[2,3]$ would be too diffuse and thus provide results that were overly sensitive and poorly specific.

With regard to validation, we previously validated the probe design (unpublished data) in open resection cases and compared it to a standard monopolar stimulation device and found an almost one to one ratio in motor evoked potential thresholds. We did not find that by having the stimulation contact within the lumen of the outer cannula, it prevented adequate tissue contact and subsequent stimulation propagation.

We concur completely that the ideal design would incorporate the stimulation at the tip of the probe as it may allow for the detection of electrophysiological changes during needle advancement. The concept of Dr Cabrera of placing a single-needle electrode, as a cost effective solution, to the outer cannula is ingenious. In our design, we attempted to have a single use internal stylet that would be compatible with an existing commercially available neuronavigation probe, and hopefully this too would limit the costs involved. The

Jason Labuschagne

Jason.labuschagne@icloud.com

1 Department of Neurosurgery, University of the Witwatersrand, Johannesburg, South Africa

2 Department of Paediatric Neurosurgery, Nelson Mandela Children's Hospital, 6 Jubilee Rd, Parktown, Johannesburg 2193, South Africa extent to which placing the stimulation at the tip of the probe will lower iatrogenic injury is however debatable. As we pointed out [1], brainstem injury could be a result of the passage of the biopsy needle or from the tissue cutting action; however, if one compares the haemorrhagic risks of procedures that involve "needle passage" only, such as deep brain stimulation [4] cases versus those in which biopsies [5] are also taken, the results tend to support the concept that the majority of injury occurs due to the cutting action of the biopsy needle, i.e., at the biopsy window site.

We sincerely thank Dr Cabrera for his comments and interest in our manuscript.

\section{Declarations}

Conflicts of interest Jason Labuschagne declares that he has a patent pending on the minimally invasive probe described in the manuscript.

\section{References}

1. Labuschagne J, Mutyaba D, Nel J, Casieri C (2021). Use of intraoperative stimulation of brainstem lesion target sites for frameless stereotactic biopsies. Child's Nervous System.

2. Pallud J, Mandonnet E, Corns R, Dezamis E, Parraga E, Zanello M, Spena G (2017) Technical principles of direct bipolar electrostimulation for cortical and subcortical mapping in awake craniotomy. Neurochirurgie 63:158-163

3. Haglund MM, Ojemann GA, Blasdel GG (1993) Optical imaging of bipolar cortical stimulation. J Neurosurg 78:785-793

4. Ben-Haim S, Asaad WF, Gale JT, Eskandar EN (2009) Risk factors for hemorrhage during microelectrode-guided deep brain stimulation and the introduction of an improved microelectrode design. Neurosurgery 64:754-762

5. Malone H, Yang J, Hershman DL, Wright JD, Bruce JN, Neugut AI (2015) Complications following stereotactic needle biopsy of intracranial tumors. World Neurosurg 84:1084-1089

Publisher's note Springer Nature remains neutral with regard to jurisdictional claims in published maps and institutional affiliations. 